\title{
Characterisation of different parts from Moringa oleifera regarding protein, lipid composition and extractable phenolic compounds
}

\author{
Mostafa Owon ${ }^{1}$, Mohamed Osman ${ }^{1}$, Awatif Ibrahim ${ }^{2}$, Mohamed Abdelbaset Salama ${ }^{3 *^{*}}$ \\ and Bertrand Matthäus ${ }^{4}$ \\ ${ }^{1}$ Food Technology Department, Faculty of Agriculture, Kafrelsheikh University, Kafrelsheikh 33511, Egypt \\ ${ }^{2}$ Food Technology Research Institute, Agriculture Research Center, Giza 12611, Egypt \\ ${ }^{3}$ Food Technology Research Institute, Agriculture Research Center, Sakha, Kafrelsheikh 33511, Egypt \\ ${ }^{4}$ Max Rubner-Institut (MRI), Department of Safety and Quality of Cereals, Working Group for Lipid Research, Detmold 32756, Germany
}

Received 12 April 2021 - Accepted 14 September 2021

\begin{abstract}
Fatty acids, amino acids, as well as total phenolic content and antioxidant activities, were presented from Moringa oleifera different parts (whole seeds, kernels, coats, pods and leaves). The investigated parts were a good source of protein $(29.2,37.8,11.9,10.1$ and $22.8 \mathrm{~g} / 100 \mathrm{~g}$ for whole seeds, kernels, coats, pods and leaves, respectively) with isoleucine, leucine, arginine, glycine, glutamine and tyrosine as amino acids in sufficient amount to meet the nutritional needs. Moringa seeds are also rich in oil. Oleic acid was the most abundant fatty acid in moringa seeds $(66.2$ and $65.8 \%$ for whole seeds and kernels, respectively). Leaves were rich in minerals such as $\mathrm{P}, \mathrm{K}, \mathrm{Mg}$ and Fe with the highest amount of total phenolic content. $70 \%$ ethanol, $80 \%$ methanol or water showed the highest yield with of total phenolic content from leaves reaching $11.8,11.3$ and $8.9 \mathrm{mg} \mathrm{GAE} / \mathrm{g}$, respectively. The lowest ED50 values were reported for extracts of leaves obtained by $70 \%$ ethanol and $80 \%$ methanol $(0.51$ and $0.54 \mathrm{mg})$, respectively, indicating more antioxidant activity than for the other solvents. For the $\beta$-carotene-linoleic acid assay, leaves extract showed also the strongest effect for delaying the oxidation followed by extracts from pods and coats in a comparison with the control without antioxidants. From this comprehensive investigation of the different parts of MO, an assessment of the raw materials regarding their application as food is possible.
\end{abstract}

Keywords: amino acids / antioxidant activity / fatty acids / Moringa oleifera / ß-carotene-linoleic acid assay

Résumé - Caractérisation de différentes parties de Moringa oleifera en termes de composition en protéines, lipides et composés phénoliques extractibles. Différentes parties de Moringa oleifera (graines entières, amandes, enveloppes, gousses et feuilles) ont été évaluées en termes de composition en acides gras, acides aminés, composés de phénoliques totaux et des activités antioxydantes. Les parties étudiées se sont révélées être une bonne source de protéines (respectivement 29,2, 37,8, 11,9, 10,1 et $22,8 \mathrm{~g} / 100 \mathrm{~g}$ pour les graines entières, les amandes, les enveloppes, les gousses et les feuilles) avec des acides aminés comme l'isoleucine, la leucine, l'arginine, la glycine, la glutamine et la tyrosine en quantité suffisante pour répondre aux besoins nutritionnels. Les graines de moringa sont également riches en huile, l'acide oléique étant l'acide gras le plus abondant (66,2 et 65,8\% pour les graines entières et les amandes, respectivement). Les feuilles étaient riches en minéraux tels que $\mathrm{P}, \mathrm{K}, \mathrm{Mg}$ et $\mathrm{Fe}$, avec la plus forte teneur en composés phénoliques totaux. L'éthanol à $70 \%$, le méthanol à $80 \%$ ou l'eau offrent le rendement le plus élevé avec un contenu phénolique total des feuilles atteignant $11,8,11,3$ et $8,9 \mathrm{mg} \mathrm{GAE} / \mathrm{g}$, respectivement. Les valeurs ED50 les plus basses ont été rapportées pour les extraits de feuilles obtenus avec $70 \%$ d'éthanol et $80 \%$ de méthanol $(0,51$ et $0,54 \mathrm{mg})$, respectivement, indiquant une activité antioxydante plus importante que les extraits obtenus avec les autres solvants. Pour le test de blanchiment du B-carotène, l'extrait de feuilles a également montré l'effet le plus fort pour retarder l'oxydation, suivi par les extraits de gousses et d'enveloppes, en comparaison avec le contrôle sans antioxydant. Cette étude complète des différentes parties de MO a permis d'évaluer les matières premières en vue de leur application alimentaire.

Mots clés : acides aminés / activité antioxydante / acides gras / Moringa oleifera / test de blanchiment du ß-carotène

*Correspondence: mohamedabdelbasetsalama@gmail.com 


\section{Introduction}

Moringa oleifera (MO) is the most famous species of the family Moringaceae and one of the thirteen members of the genus Moringa (Morton, 1991). The plant is a fast-growing tree that is resistant of drought, making it interesting for arid and semi-arid regions. The tree has many traditional names such as horseradish or drumstick. MO seeds are inside of pods and have a triangle or round shape. The kernels are covered by a coat that can be easily removed (Abdulkarim et al., 2005). About 400-1000 pods and 15 000-25 000 seeds could be taken from each tree per year. The ratio of the kernels to the coat is 75:25 (Jahn, 1988). Because of its many uses, tolerance to varieties of soils and climates, and ease of multiplication, MO has become extremely popular all over the world (Kasolo et al., 2010). Moreover, it is considered a good food ingredient because of its bioactive compounds content (Brilhante et al., 2017; Ma et al., 2020). Moringa leaves powder is used to fight malnutrition in children and pregnant women diets (Kuku-Shittu et al., 2016). In addition, it is used in water purification (Rahman et al., 2010).

Generally, all MO is very rich in oil with oleic acid as the main fatty acid, similarly to olive oil (Gharby et al., 2018, 2021) with a great potential to become a promising commercial source of edible oil for the food industry. Also, the other main fatty acids of olive oil can be found in MO oil (Nadeem and Imran, 2016). Since ancient times, MO oil is used for perfume and cosmetic production, as lubricants in machinery and recently for biodiesel production (Fernandes et al., 2015). Resulting from the fatty acid composition, the most dominant polyunsaturated triacylglycerol (TAG) in MO oil is triolein "OOO" which reaches about 36.7\% (Abdulkarim et al., 2005; Salama et al., 2020). The oil has higher stability during frying than canola oil, soybean oil and palm olein (Abdulkarim et al., 2007) and it smells like peanut (Kleiman et al., 2008). MO oil is used to make perfume and products for hair protection (Tsaknis et al., 1999). Other parts of MO are also used as vegetable food in some countries (Siddhuraju and Becker, 2003). It has been published that MO leaves contain a significant amount of $\mathrm{Ca}, \mathrm{Na}, \mathrm{Fe}, \mathrm{Cu}, \mathrm{Zn}$ and $\mathrm{Mg}$ (Gowrishankar et al., 2010). In addition, MO leaves contain essential oil which has antimicrobial activities (Marrufo et al., 2013). MO dried leaves are also an important source of polyphenolic compounds (Pandey and Rizvi, 2009). This class of compounds plays a vital role in the protection against chronic diseases associated with oxidative stress, including cardiovascular disease and cancer (Jara-Palacios et al., 2015). Phenolic acids are a sub-group of phenolic compounds, derived from hydroxybenzoic and hydroxycinnamic acids, and have many useful properties like anticancer, antioxidant and anti-inflammatory properties (Verma et al., 2009). Many parts of MO tree have a significant amount of essential amino acids (Amagloh and Benang, 2009). The protein from MO roots, leaves and seeds is suitable for animal feed and human diet (Okereke and Akaninwor, 2013). Furthermore, MO is a good source of vitamins and B-carotene (Anwar et al., 2007). In summary, much useful information about the composition of MO seeds is already available from several publications, but there is not enough information about the other parts of MO. The aim of this research was to provide first information about fatty acids, amino acids, total phenolic contents and their antioxidant activity of the different parts of MO (whole seeds, kernels, coats, pods and leaves) beside chemical composition and minerals content.

\section{Materials and methods}

\subsection{Plant materials}

Materials used in this investigation were purchased from Agricultural Research Center (Sakha, Kafrelsheikh, Egypt). Harvesting was carried out in August 2018 and care was taken to collect a representative sample. Mature MO pods were dried and then opened to collect the seeds from inside. The seeds were sun-dried. After that, the coat was removed before grinding the seed. Leaves were air-dried and stored until use.

\subsection{Reagents}

Petroleum ether $\left(40-60^{\circ} \mathrm{C}\right)$ was of analytical grade $(>98 \%$; Merck, Darmstadt, Germany). Tert-butyl methyl ether, heptane (HPLC grade), tocopherol, tocotrienol standard compounds and Folin-Ciocalteau reagent were purchased from Merck (Darmstadt, Germany). Standard FAME was obtained from Restek (Bad Homburg, Germany). ß-carotene was obtained from Fluka (Munich, Germany). Linoleic acid was obtained from Alfa Aesar (Ward Hill, Massachusetts, USA) and gallic acid was purchased from Sigma Aldrich (Munich, Germany).

\subsection{Methods}

\subsubsection{Chemical composition}

Moisture content was measured using air-oven $\left(100^{\circ} \mathrm{C}\right)$ following official methods of AOAC (2010) (Method No.925.10) till constant weight. Crude protein content $(\mathrm{N} \times 6.25)$ was determined in accordance with the Kjeldahl method (Method No.920.87). Ash content was assayed by incinerating the samples in a muffle furnace at $550{ }^{\circ} \mathrm{C}$ (Method No.923.03). Crude fat was determined by Soxhlet extraction method using petroleum ether as the extract agent $\left(60-80^{\circ} \mathrm{C}\right)$. Carbohydrates were calculated by difference as follows: Carbohydrates $=[100-(\%$ moisture $+\%$ lipids $+\%$ proteins $+\%$ total dietary fibre $+\%$ ash $)]$.

\subsubsection{Oil extraction}

The oil extraction was performed according to method ISO standard (ISO 659, 2009) by hot extraction using a Twisselmann apparatus. In brief, $5 \mathrm{~g}$ of sample (whole seeds, kernels, coats and leaves) were grinded in a mill (IKA, model A11 BS000, Germany) and extracted using $75 \mathrm{~mL}$ petroleum ether in a Twisselmann apparatus for $6 \mathrm{~h}$. The solvent was evaporated by a rotary evaporator at $40^{\circ} \mathrm{C}$ and 25 Torr (model RV 10C S93, IKA-Werke GmbH \& Co. KG, Stauffen, Germany). The oil was dried by nitrogen after removing the solvent, filtered and stored at $4{ }^{\circ} \mathrm{C}$ until use.

\subsubsection{Mineral composition}

Minerals content were carried out using Atomic Absorption (NC. 9423-400-30042, England) by techniques described by AOAC (2010). 


\subsubsection{Amino acids composition}

In brief, the sample $(0.1 \mathrm{~g})$ was hydrolysed using $10 \mathrm{~mL}$ of $6 \mathrm{~N}$ hydrochloric acid with $0.1 \%$ mercapto ethanol in an evacuated tube at $110^{\circ} \mathrm{C}$ for $24 \mathrm{~h}$. After cooling at room temperature, the hydrolyzed sample was filtered through Whatman No. 1. filter paper after that the filtrate was diluted with distilled water to $25 \mathrm{~mL}$. Five $\mathrm{mL}$ of the diluted filtrate was dried in a vacuum desiccator in the presence of potassium hydroxide. The residue was dissolved in $1 \mathrm{~mL}$ of sodium citrate buffer ( $\mathrm{pH}$ 2.2) and stored at $4{ }^{\circ} \mathrm{C}$ until analysis by using amino acid analyzer (Beckman amino acid analyzer, Model 119CI) (Duranti and Cerletti, 1979). P-PER (predicted protein efficiency ratio) was measured using the followed equation: P-PER $=-0.468+0.454$ (Leu) -0.105 (Tyr) (Alsmeyer et al., 1974).

\subsubsection{Fatty acids composition}

The fatty acids composition was determined following the DGF-C-VI 10 (13) (DGF, 2013) in combination with DGF-C-VI 11d (98) (DGF, 2013). Before analysis, fatty acids (FAs) were converted to fatty acid methyl esters (FAMEs) by dissolving MO oil sample (1 drop) in n-heptane $(1 \mathrm{~mL})$, after that sodium methylate $(50 \mu \mathrm{g})$ was added and for $60 \mathrm{~s}$ the tube was agitated at room temperature. After stopping the reaction by addition of water $(100 \mu \mathrm{L})$, neutralization of the solution with $50 \mu \mathrm{L}$ of $\mathrm{HCl}$ (1 mol with methyl orange (Merck, Darmstadt, Germany)) and drying with sodium hydrogen sulphate $(20 \mathrm{mg})$. The upper phase of $\mathrm{n}$-heptane was transferred to a vial and injected in GC (HP5890, Agilent Technologies Sales \& Services GmbH \& Co. KG, Waldbronn, Germany), equipped with a FID, with a capillary column, CP-Sil 88 (100 m long, $0.25 \mathrm{~mm}$ ID, film thickness $0.2 \mu \mathrm{m}$ ). The temperature program was as follows: from $155^{\circ} \mathrm{C}$; heated to $220^{\circ} \mathrm{C}\left(1.5^{\circ} \mathrm{C} / \mathrm{min}\right), 10 \mathrm{~min}$ isotherm; injector $250^{\circ} \mathrm{C}$, detector $250^{\circ} \mathrm{C}$; carrier gas $36 \mathrm{~cm} / \mathrm{s}$ hydrogen; split ratio 1:50; detector gas $30 \mathrm{~mL} / \mathrm{min}$ hydrogen; $300 \mathrm{~mL} / \mathrm{min}$ air and $30 \mathrm{~mL} / \mathrm{min}$ nitrogen; manual injection volume less than $1 \mu \mathrm{L}$. The integration program was used to calculate the peak areas and by using direct internal normalization. Each individual FA was expressed as the relative percentage in the sample.

\subsubsection{Extraction of phenolic compounds}

One gram of each sample (leaves, coats, pods, whole seeds and kernels) was soaked in $10 \mathrm{~mL}$ of different solvents (acetone, methanol, ethanol, water, 80\% methanol and $70 \%$ ethanol). Samples were sonicated for $30 \mathrm{~min}$ in a bath-type sonicator. Afterwards, the extract for 5 min was centrifuged at $3000 \times \mathrm{g}$, the supernatant solvent was collected in a $500 \mathrm{~mL}$ flask and the resulting insoluble residue was treated twice as mentioned above. The combined supernatants were concentrated at $40^{\circ} \mathrm{C}$ by a rotary evaporator (model RV $10 \mathrm{C} \mathrm{S} 93$, IKA-Werke GmbH \& Co. KG, Stauffen, Germany) and then stored in a fridge until use.

\subsubsection{Total phenolic compounds}

Moringa different parts $(1 \mathrm{~g})$ were dissolved in $10 \mathrm{~mL}$ of different solvents and extracted using ultrasonic for $30 \mathrm{~min}$. After centrifugation $(3000 \times \mathrm{g}$ for $5 \mathrm{~min})$, the supernatant was filtered into a $50 \mathrm{~mL}$ flask. This method was repeated twice. The supernatant was evaporated at $40^{\circ} \mathrm{C}$ by using rotary evaporator under vacuum. The residue was completely dissolved with methanol/water $(1 \mathrm{~mL})(60: 40)$ (ultrasonic bath) and then transferred into a $5 \mathrm{~mL}$ flask. The $50 \mathrm{~mL}$ flask was washed twice with methanol/water $(1 \mathrm{~mL})(60: 40)$. After that, the $5 \mathrm{~mL}$ flask was filled with $0.3 \% \mathrm{MeOH}-\mathrm{HCl}$. A $100-\mu \mathrm{L}$ aliquot of the resulting solution was added to $2 \%$ $\mathrm{Na}_{2} \mathrm{CO}_{3}(2 \mathrm{~mL})$ and after $2 \mathrm{~min}, 50 \mu \mathrm{L}$ of Folin-Ciocalteau reagent was added. After a further $30 \mathrm{~min}$ at $750 \mathrm{~nm}$, the absorbance was measured. The concentration was measured using gallic acid as standard and the results were expressed as milligrams gallic acid equivalents (GAE) per gram sample.

\subsection{8 $\mathrm{DPPH}$ radical scavenging}

2,2-diphenyl-1-picrylhydrazyl (DPPH) (Sigma, Steinheim, Germany) radical was used for the evaluation of the antioxidant activity by the DPPH assay. For each extract, different concentrations were tested. An aliquot $(0.5 \mathrm{~mL})$ of the DPPH solution (about $50 \mathrm{mg} / 100 \mathrm{~mL}$ ) was diluted in $4.5 \mathrm{~mL}$ of methanol and $0.1 \mathrm{~mL}$ of an extract solution was added. The mixture was shaken and left in the dark (45 $\mathrm{min})$. The reduction in absorbance was reported at $515 \mathrm{~nm}$ against a blank. From different amounts of extract, a calibration curve was done to calculate the ED50 (Hatano et al., 1988). The concentration of an antioxidant, which was used to quench $50 \%$ of the initial DPPH radicals, is called ED50.

\subsubsection{B-carotene bleaching method}

In brief, $40 \mathrm{mg}$ of linoleic acid and $400 \mathrm{mg}$ of Tween 20 were transferred into a flask, and a solution of $\beta$-carotene $(1 \mathrm{~mL})(6 \mathrm{mg} / \mathrm{mL})$ in chloroform was added. Chloroform was removed at $40^{\circ} \mathrm{C}$ by rotary evaporation (IKA, model RV $10 \mathrm{CS} 93$ ). Then, distilled water $(100 \mathrm{~mL})$ was added to the residue and the solution was agitated to make an emulsion. To an aliquot of this emulsion $(5 \mathrm{~mL}), 0.2 \mathrm{~mL}$ of an antioxidant solution was added and the absorbance was measured at $470 \mathrm{~nm}$ immediately, against a blank consisting of the emulsion without $B$-carotene. The tubes were put in a water bath $\left(40^{\circ} \mathrm{C}\right)$ (HAAKEC 10) and the absorbance was measured by spectrometer (Analytik Jena Specord 250) every 15 min up to $60 \mathrm{~min}$ and then after $120 \mathrm{~min}$ (Taga et al., 1984).

\subsubsection{Statistical analyses}

Data were processed with the software of SPSS (Version 16.0, SPSS Inc., Chicago, IL) to test the variance by one-way analysis of variance (ANOVA) method. The means and the standard deviations were calculated of three repetitions.

\section{Results and discussion}

Different parts of $\mathrm{MO}$ are in use in many parts of the world, especially in arid regions to ensure the nutrition of the rural population. The most important material is the seeds, but meanwhile, applications for leaves, pods or the coat came in the focus of interest. For further evaluation of the suitability of these materials for use in nutrition or for food applications, more knowledge on the composition is necessary. 


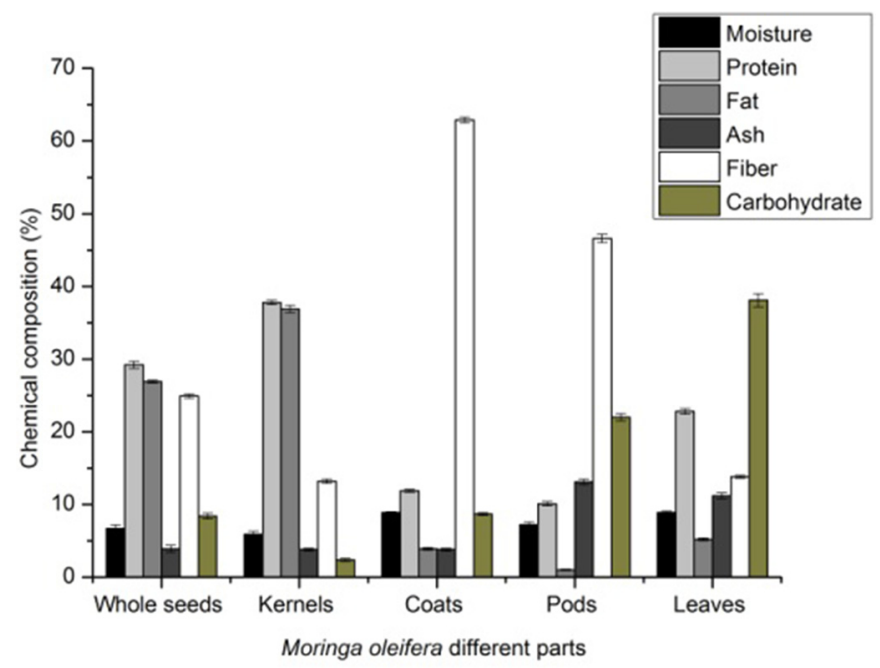

Fig. 1. Chemical composition (\%) of the different parts of Moringa oleifera (whole seeds, kernels, coats, pods and leaves).

\subsection{Proximate composition}

For a comprehensive evaluation of the quality of the different parts of $\mathrm{MO}$, the chemical composition was done. The further use for human or animal nutrition depends on the amount of protein and fat, but also on the content of carbohydrates and fibre. A high fat amount results in an interesting resource for oil processing. On the other side, a high value of protein is decisive for the use in human or animal nutrition. Figure 1 showed the chemical composition of the different parts of MO. The largest amount of oil and protein was represented in the kernels obtained after removal of the seed coat and wing with roughly same proportions of about $37 \%$. The oil content was comparable to sunflower or rapeseed seeds but higher than for soybeans (Raß et al., 2008; Sultan et al., 2015; Xie et al., 2019). Looking on the protein content reveals a significant higher content than for sunflower seed but comparable to soybeans and rapeseeds (Carré et al., 2016; Guo et al., 2017; Seo et al., 2012). This shows that kernels from MO are combining the advantages of the oilseed rapeseed and the protein supplier soybean.

The removal of the coat from the seeds resulted in a better raw material for further use in human nutrition by enrichment of protein and fat, resulting from the removal of the high fibre content coat $(62.9 \%)$. These data are in a harmony with the results mentioned by Abiodun et al. (2012) and Rahman et al. (2009) who reported that moisture, protein and ash content in the seeds were $(4.7-7.1 \%),(28.0-31.8 \%)$ and $(4.1-6.3 \%)$, respectively. Moreover, Anwar and Bhanger (2003) and Compaoré et al. (2011) mentioned that the protein amount in the seeds was $29.4 \%$ and $35.4 \%$, respectively. El-Massry et al. (2013) found moisture $(4.7 \%)$, protein $(26.0 \%)$, fibre $(4.9 \%)$, total carbohydrates $(14.4 \%)$, and fat $(44.8 \%)$ for seeds in the same range as in the current investigation. For the oil content of the seeds, Tsaknis et al. (1999), Lalas and Tsaknis (2002) and Anwar et al. (2005) reported 35.7\%, 38.3\% and 33.2\%, respectively. Leaves and pods were characterized by a large content of carbohydrates in comparison to the other plant materials from $\mathrm{MO}(38.1 \%$ and $22.0 \%$, respectively). A similar amount was also found by El-Massry et al. (2013) who reported $35.9 \%$ in dried leaves. This may be of particular interest for the production of carbohydrates from these materials. Besides the seeds, the leaves $(22.8 \%)$ also contained remarkable high amount of protein giving an indication of their usefulness in human diet and especially as livestock feed. Similar amounts of protein were presented by El-Massry et al. (2013) (26.8\%) and Mukunzi et al. (2011) (25.3\% for leaves from Ruanda) while Moyo et al. (2011) (30.3\%) and Mukunzi et al. (2011) (29.5\% for leaves from China) found little higher amounts of protein in dry leaves. The protein amount found by El-Massry et al. (2013) for pods was higher than in the current investigation (17.2\%). In comparison to the seeds and leaves, protein amount was low in coat $(11.9 \%)$ and pods $(10.1 \%)$, but they could still be used as high-fibre raw material to supplement animal feeds. Leaves (11.2\%) and pods (13.1\%) reported the highest amount of ash which is three times more than in the other materials and that makes leaves and pods a good source of minerals (Melesse, 2011) in human nutrition or as animal feed. Similar high amounts of ash were reported by Mukunzi et al. (2011) for dry MO from China (13.4\%) and Rwanda (17.3\%), while Moyo et al. (2011) and El-Massry et al. (2013) reported remarkable lower amounts of ash in dry leaves of MO (7.6\% and $7.9 \%$, respectively). The oil content in coats, pods and leaves in the present investigation was low with amounts of $3.9 \%, 1.0 \%$ and $5.2 \%$, respectively, making these materials uninteresting for an economical oil extraction. This was close to other investigations showing also the low fat content of pods $(0.4 \%)$ and leaves $(5.0 \%)$ (El-Massry et al., 2013), and the variation of the fat content, depending on the origin of the leaves $(7.6 \%$ China or $6.5 \%$ Rwanda) (Mukunzi et al., 2011). The results show that the different parts of MO are interesting raw materials for protein, carbohydrates or minerals beyond the fat content of the seeds. Especially, the leaves show a promising composition with regard to the content of carbohydrates, minerals, and protein, making a further use as food or in food applications interesting. Although coats and pods are only by-products of the production of kernels, they are usable in animal nutrition as fibre-rich raw material with a low content of protein.

\subsection{Mineral composition}

Data in Table 1 showed that MO dry leaves had a high amount of ash, resulting in a high content of $\mathrm{P}, \mathrm{Mg}, \mathrm{Zn}, \mathrm{K}, \mathrm{Na}$, Fe and Mn $(2565,3820,64.5,16250,694.5,1300$, and $64.5 \mathrm{mg} / \mathrm{kg}$, respectively), in comparison to the seeds or the meal obtained from the seeds by removal of oil. Remarkable high is the content of $\mathrm{Mg}$ and $\mathrm{K}$ making the leaves a good source for these minerals. This is in agreement with values published by El-Massry et al. (2013) who also found remarkable high amounts for $\mathrm{Mg}(4036 \mathrm{mg} / \mathrm{kg})$ and $\mathrm{K}(14988 \mathrm{mg} / \mathrm{kg})$. Also, the results of the other minerals were close to the current work, $\mathrm{P}(3469 \mathrm{mg} / \mathrm{kg}), \mathrm{Zn}(54.3 \mathrm{mg} / \mathrm{kg})$, $\mathrm{Na}(725 \mathrm{mg} / \mathrm{kg}), \mathrm{Fe}(277.6 \mathrm{mg} / \mathrm{kg})$ and $\mathrm{Mn}(324.5 \mathrm{mg} / \mathrm{kg})$. Gopalakrishnan et al. (2016) mentioned similar values for the minerals in leaves. In our paper, the minerals amounts in seeds and meal were significant lower than in the leaves for all compounds, but higher than reported by other researchers. Abiodun et al. (2012) found much lower values 
Table 1. Minerals composition $(\mathrm{mg} / \mathrm{kg})$ of different plants parts of Moringa oleifera (leaves, whole seeds and meal).

\begin{tabular}{lrcr}
\hline Minerals & \multicolumn{1}{c}{ Leaves } & Whole seeds & \multicolumn{1}{c}{ Meal } \\
\hline $\mathrm{P}$ & $2565 \pm 4$ & $1430 \pm 3$ & $2220 \pm 3$ \\
$\mathrm{Mg}$ & $3820 \pm 6$ & $2810 \pm 1$ & $3320 \pm 3$ \\
$\mathrm{Zn}$ & $64.5 \pm 1$ & $28.5 \pm 2$ & $14.5 \pm 3$ \\
$\mathrm{~K}$ & $16250 \pm 7$ & $8405 \pm 4$ & $10265 \pm 5$ \\
$\mathrm{Na}$ & $694.5 \pm 3$ & $72 \pm 5$ & $78 \pm 2$ \\
$\mathrm{Fe}$ & $1300 \pm 6$ & $73.5 \pm 2$ & $80 \pm 2$ \\
$\mathrm{Mn}$ & $64.5 \pm 4$ & $12.5 \pm 2$ & $14.5 \pm 3$ \\
\hline
\end{tabular}

Meal $=$ After oil extraction from the whole seeds.

for $\mathrm{Na}(155 \mathrm{mg} / \mathrm{kg})$ and $\mathrm{Fe}(31.0 \mathrm{mg} / \mathrm{kg})$ in MO flour, but with a comparable dominance for $\mathrm{Mg} \quad(220.1 \mathrm{mg} / \mathrm{kg})$ and $\mathrm{K}(479 \mathrm{mg} / \mathrm{kg})$. Sodium found in the current work was lower than the values observed by Nzikou et al. (2009) for seeds $(225.0 \mathrm{mg} / \mathrm{kg})$. The high amounts of minerals found in the different parts suggest that MO can contribute to the supply with minerals in human and animal nutrition. Since the body cannot produce them, the uptake with food or feed is necessary to avoid disadvantages when growing or maintaining of the body or regulatory functions. Especially, the leaves could be a valuable source for minerals, but also the meal after enriching the mineral content by extraction of oil.

\subsection{Amino acid composition}

Table 2 showed the essential and non-essential amino acids composition of whole seeds, kernels, coats and leaves. The total content of amino acids of MO leaves, coat, whole seeds and kernels were 91.8, 95.5, 79.5 and $80.4 \mathrm{~g} / 100 \mathrm{~g}$ crude protein, respectively (Tab. 2).

The amino acid composition of all materials showed comparable amounts for both classes of amino acids with values between $35.8 \mathrm{~g} / 100 \mathrm{~g}$ protein (seeds) and $41.9 \mathrm{~g} / 100 \mathrm{~g}$ (leaves) for essential amino acids and between $43.2 \mathrm{~g} / 100 \mathrm{~g}$ (kernels) and $54.5 \mathrm{~g} / 100 \mathrm{~g}$ (pods) for non-essential amino acids. The essential amino acids valine, threonine, isoleucine, lysine and leucine showed significant higher amounts in leaves and coat in comparison to the seeds or kernels and also for nonessential amino acids higher values were found in leaves and pods in comparison to the seeds or kernels. Methionine had a low concentration in all the samples ranging between 1.5 and $2.0 \mathrm{~g} / 100 \mathrm{~g}$ protein. This low amount of methionine content agrees with the fact that methionine is the most limiting essential amino acid in leguminous seeds. The highest amount of an individual amino acid was found for glutamine as non-essential amino acid with similar amounts in leaves $(15.0 \mathrm{~g} / 100 \mathrm{~g})$, coat $(17.5 \mathrm{~g} / 100 \mathrm{~g})$, whole seeds $(16.6 \mathrm{~g} / 100 \mathrm{~g})$, and kernels $(16.3 \mathrm{~g} / 100 \mathrm{~g})$, respectively. Especially coats, whole seeds and kernels were dominated by arginine with values higher than $10 \mathrm{~g} / 100 \mathrm{~g}$, only the amount in the leaves was lower $(5.8 \mathrm{~g} / 100 \mathrm{~g})$. The essential amino acids amounts were in the range of the recommendation given by FAO/UN/WHO (1991) (Tab. 2) for the supply with amino acids for adults, while in seeds and kernels these amino acids were below this recommendation except for isoleucine and leucine.

$\mathrm{P}-\mathrm{PER}$ is one quality parameter used for protein evaluation (FAO/UN/WHO, 1991). Results indicated that leaves had the highest P-PER (2.63) followed by coats (1.8) (Tab. 2). Much of protein benefits may be attributed to leucine due to its ability to stimulate protein synthesis, helping to turn on the body's switch to build muscle and spare muscle when dieting (Layman and Walker, 2006). Leucine content above $5.0 \mathrm{~g} / 100 \mathrm{~g}$ protein often results to appreciable P-PER (Amaechi et al., 2015). P-PER below 1.5 describes a protein of low or poor quality (Friedman, 1996). Even if the P-PER values of whole seeds and kernels were low, the results showed that the different parts of MO are valuable sources for the supply of amino acids either for human or animal nutrition. Especially, dry leaves are a promising source of valuable protein due to the high protein content comparable to rapeseed and an amino acid composition which is as far as possible in line with the recommendations. Only the low content of methionine is a limitation.

\subsection{Fatty acid composition}

Figures $2 \mathrm{~A}$ and $2 \mathrm{~B}$ showed the fatty acid composition of oil extracted from whole seeds, kernels, coats and leaves. The oil content of pods was too low to carry out the investigation of the fatty acid composition. The results showed that oleic acid was the main unsaturated fatty acid in whole seeds, kernels and coats $(66.2,65.8$ and $57.8 \mathrm{~g} / 100 \mathrm{~g})$. This high amount of oleic acids is comparable to rapeseed oil and only a little lower than for olive oil making MO oil preferable in nutrition and cooking (Abdulkarim et al., 2005). Behenic acid was the second abundant fatty acid in seeds, kernels and coats of MO. Only in leaves, the amount of behenic acid was significant lower than in the other parts of the plant. In comparison to other edible oils, MO oil from different parts of the plant contained high amounts of behenic acid (2.4-7.3 g/100 g) while in oils such as rapeseed or sunflower oils only 0.5 to $2 \mathrm{~g} / 100 \mathrm{~g}$ were found (Codex, 2019). Only peanut oil contains up to $3.25 \mathrm{~g} / 100 \mathrm{~g}$ (Konuskan et al., 2019). The results for behenic acid found in the current paper were similar to others, reported by Abdulkarim et al. (2005), Anwar et al. (2005) and Rashid et al. (2008), respectively. Nguyen et al. (2011) extracted the oil from moringa kernels by using supercritical carbon dioxide and found an amount of $6.7 \mathrm{~g} / 100 \mathrm{~g}$. Behenic acid does not belong to the essential fatty acids, but in skincare, it is most commonly used to provide soothing relief for dry and sensitive skin (Banov et al., 2014). In addition, it is discussed as a structuring and solidifying agent in margarine, shortening, and foods containing semi-solid and solid fats, without the need of hydrogenation to the oil (FDA, 2001). Vaccenic acid was the third most dominant fatty acid in MO from different parts of the plant with amounts between 6.0 and $6.3 \mathrm{~g} / 100 \mathrm{~g}$ found in oil extracted from seeds, kernels and coats. Only in leaves, no vaccenic acid was found. Most edible oils are lower in vaccenic acid (Kalo and Kemppinem, 2003). The amounts found in the current work are similar to Al Juhaimi et al. (2017). The oil from the different parts of MO contains, additionally to behenic acid, considerable amounts of saturated fatty acids, palmitic acid (5.6 (seeds) to $10.1 \mathrm{~g} / 100 \mathrm{~g}$ (leaves)), 
M. Owon et al.: OCL 2021, 28, 45

Table 2. Amino acids composition of different plant parts of Moringa oleifera (whole seed, kernel, coat, pod and leaves) (g/100 g protein).

\begin{tabular}{|c|c|c|c|c|c|}
\hline Amino acids & Leaves & Coat & Wholeseed & Kernel & FAO/WHO* \\
\hline Threonine & $4.1 \pm 0.1$ & $3.3 \pm 0.1$ & $2.5 \pm 0.1$ & $2.3 \pm 0.1$ & 3.4 \\
\hline Lysine & $4.8 \pm 0.2$ & $4.6 \pm 0.2$ & $2.2 \pm 0.2$ & $1.9 \pm 0.1$ & 5.8 \\
\hline Methionine & $1.5 \pm 0.1$ & $1.9 \pm 0.1$ & $1.8 \pm 0.2$ & $2.0 \pm 0.1$ & 2.5 \\
\hline Leucine & $7.7 \pm 0.2$ & $5.7 \pm 0.2$ & $4.9 \pm 0.4$ & $4.9 \pm 0.2$ & 1.1 \\
\hline Arginine & $5.8 \pm 0.2$ & $10.8 \pm 0.3$ & $11.8 \pm 0.1$ & $12.9 \pm 0.2$ & 5.2 \\
\hline Total essential amino acids & 41.9 & 41.1 & 35.8 & 37.2 & - \\
\hline Glycine & $4.9 \pm 0.1$ & $5.1 \pm 0.2$ & $5.0 \pm 0.4$ & $4.9 \pm 0.3$ & 2.2 \\
\hline Alanine & $6.2 \pm 0.1$ & $4.6 \pm 0.2$ & $4.3 \pm 0.4$ & $4.0 \pm 0.2$ & 6.1 \\
\hline Cycteine & $1.6 \pm 0.3$ & $3.7 \pm 0.2$ & $3.1 \pm 0.2$ & $3.8 \pm 0.2$ & 3.0 \\
\hline Proline & $5.1 \pm 0.1$ & $7.8 \pm 0.2$ & $4.8 \pm 0.2$ & $5.3 \pm 0.1$ & 10.7 \\
\hline Total non-essential amino acids & 49.8 & 54.5 & 43.7 & 43.2 & - \\
\hline Total amino acids (TAA) $\mathrm{g} / 100 \mathrm{~g}$ & 91.8 & 95.5 & 79.5 & 80.4 & - \\
\hline P-PER & 2.6 & 1.8 & 1.5 & 1.5 & - \\
\hline
\end{tabular}

*FAO/UN/WHO (1991, Reference Pattern) (g/100 g protein).
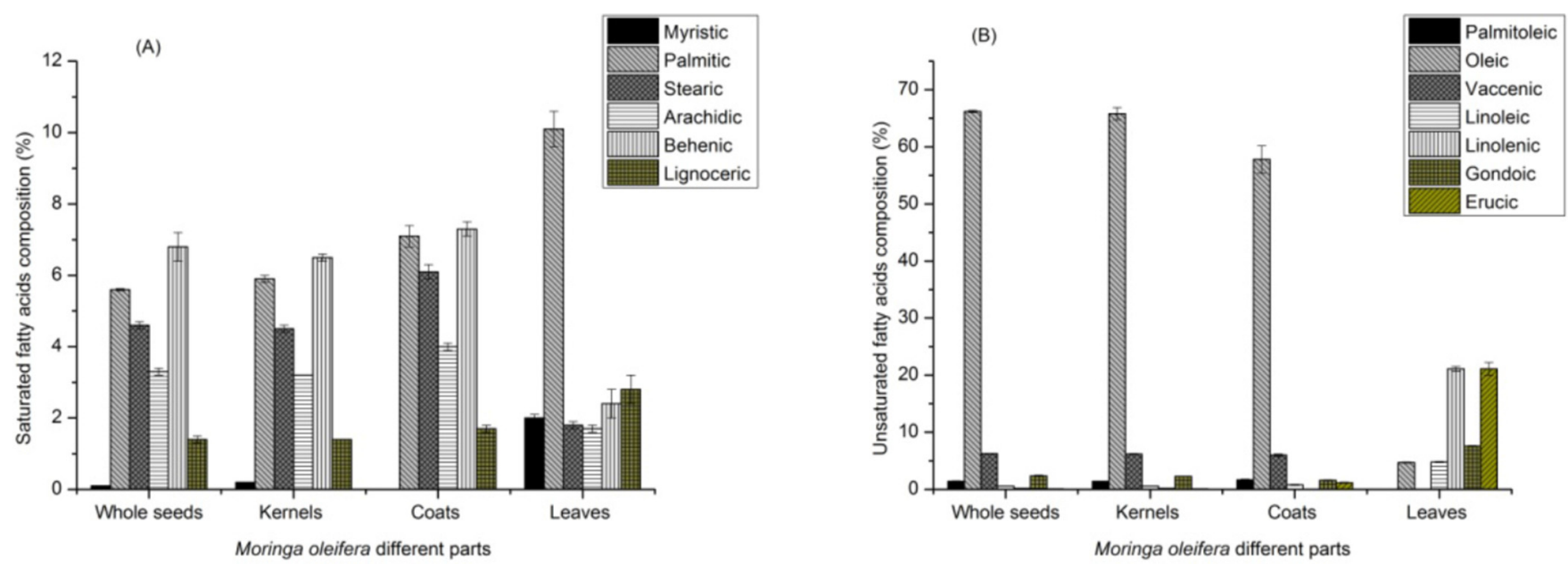

Fig. 2. Fatty acids composition (\%) of the different parts of Moringa oleifera (whole seeds, kernels, coats and leaves). (A) Saturated fatty acids. (B) Unsaturated fatty acids.

stearic acid $(1.8 \mathrm{~g} / 100 \mathrm{~g}$ (leaves) to $6.1 \mathrm{~g} / 100 \mathrm{~g}$ (coats)) and arachidic acid $(1.7 \mathrm{~g} / 100 \mathrm{~g}$ (leaves) to $4.0 \mathrm{~g} / 100 \mathrm{~g}$ (coats)). The oil from leaves also contain considerable amounts of myristic acid $(2.0 \mathrm{~g} / 100 \mathrm{~g})$ typical for coconut or palm kernel fat. The third most abundant unsaturated fatty acid was gondoic acid with amounts between $1.6 \mathrm{~g} / 100 \mathrm{~g}$ (coats) and $7.6 \mathrm{~g} / 100 \mathrm{~g}$ (leaves). The results found for seed and kernel oil are comparable to other references (Lalas and Tsaknis, 2002; Anwar and Bhanger, 2003; Salama et al., 2020). Only in leaves, linoleic and linolenic acid were present in considerable amounts $(4.8 \mathrm{~g} / 100 \mathrm{~g}$ and $21.1 \mathrm{~g} / 100 \mathrm{~g}$, respectively) while in the other parts only traces were found. For oil from leaves other references also show a dominant amount of linolenic acid $(44.6 \mathrm{~g} / 100 \mathrm{~g})$ and a higher content of palmitic acid $(11.8 \mathrm{~g} / 100 \mathrm{~g}$ ) (Moyo et al., 2011). The results show that oil from MO seeds can be very good alternative oil, rich in oleic acid such as rapeseed or olive oils. Two disadvantages of MO oil in comparison to rapeseed oil are i) the three times higher amount of saturated fatty acids and ii) the absence of linoleic and linolenic acid. 

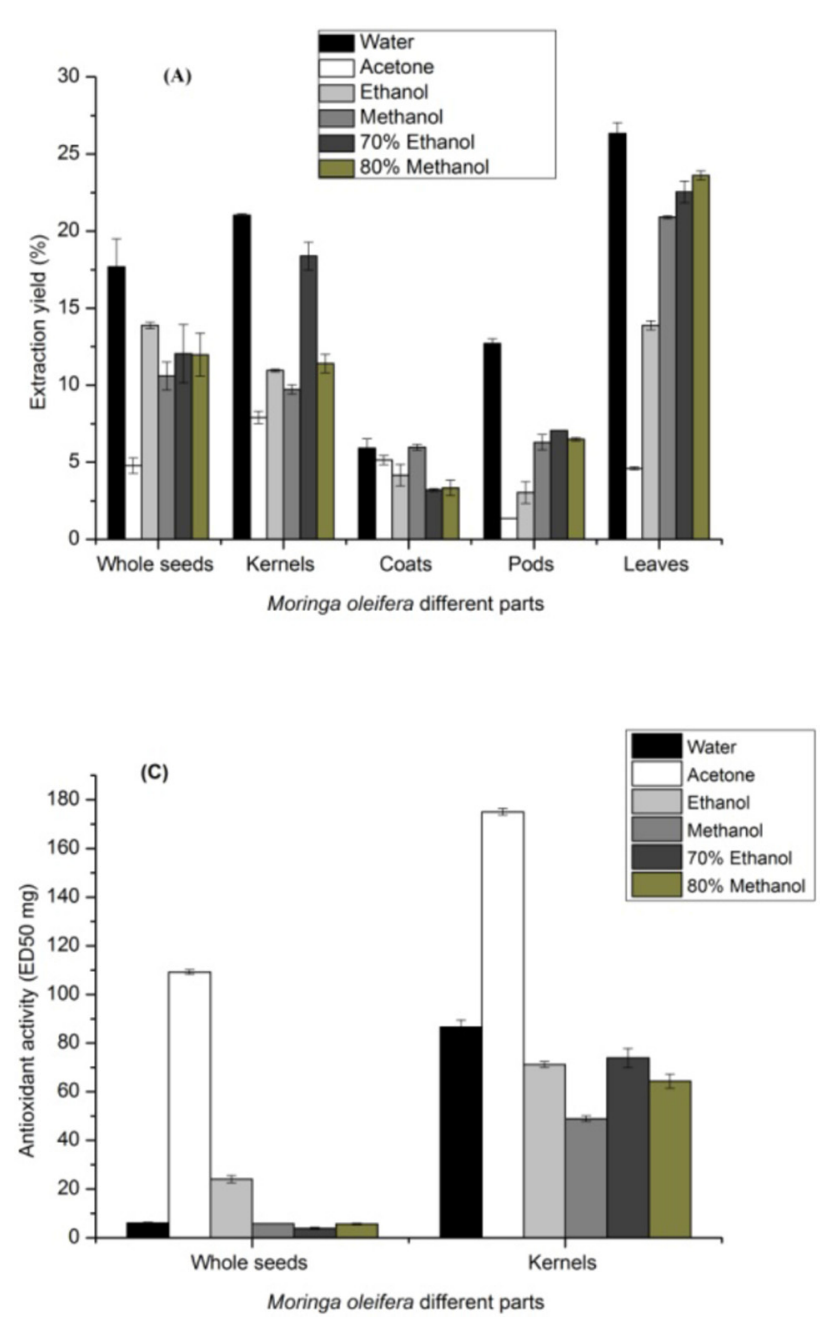
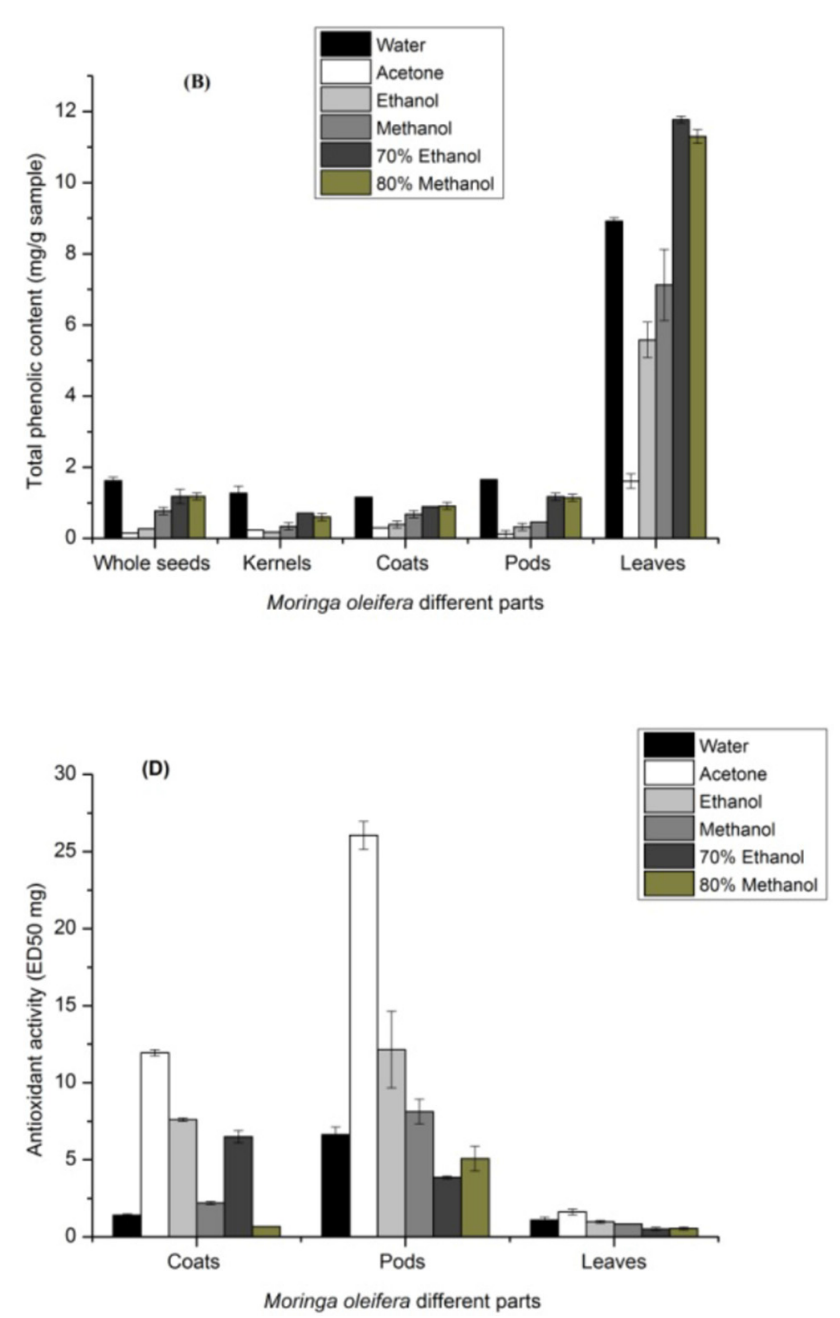

Fig. 3. Phenolic compounds evaluation of the different parts of Moringa oleifera (leaves, coats, pods, whole seeds and kernels) by using different solvents. (A) Extraction rate (\%). (B) Total phenolic compounds (mg GAE/g sample). (C) DPPH scavenging activity (ED50) (mg) of Moringa oleifera (whole seeds and kernels). (D) DPPH scavenging activity (ED50) (mg) of Moringa oleifera (coats, pods and leaves).

\subsection{Extraction rate and total phenolic compounds (TPC)}

Figure $3 \mathrm{~A}$ summarizes the extraction rate of different plant materials from MO with different solvents. The different materials contained remarkable amounts of total extractable compounds but the results also reveal that the extracting capacity of different solvents for the materials was different. In general, water was the most effective solvent to get high extraction rate from the samples. On the other side, acetone was the weakest extraction agent resulting in the lowest yield. Roughly, the amount of the extraction rate decreased with decreasing polarity of the solvent in the order water, ethanol, methanol, $80 \%$ methanol, $70 \%$ ethanol and acetone. This could be due to the polar moiety of phenolic compounds. The effect of different solvents were in agreement with Martinez-Correa et al. (2011) who indicated that aqueous extraction showed the highest amount of extraction rate from pitanga (Eugenia uniflora L.) leaves followed by ethanolic extraction and supercritical extraction. Barchan et al. (2014) found similar results about the amount of extraction rate by using water from Mentha species. They mentioned that using water as a solvent reported the major amount of extraction rate in the three species. Near findings were reported by Grigonis et al. (2005) who mentioned that extraction rate from sweet grass (Hierochlö odorata) was higher by using ethanol $95 \%$ $(21.4 \%)$ than acetone $(6 \%)$.

The extraction rate also strongly depends on the plant material with leaves showing the highest yield for the extraction with water $(26.3 \%)$ followed by kernels $(21.0 \%)$, whole seeds $(17.7 \%)$, pods $(12.7 \%)$ and coats $(5.9 \%)$.

TPC of these total extractable compounds was determined by the colorimetric based Folin-Ciocalteau assay (Fig. 3B). The results were expressed in $\mathrm{mg}$ of gallic acid equivalents (GAE) per g extract. Although the use of solvent mixed with water $(80 \%$ methanol and $70 \%$ ethanol) did not result in highest yield of extractable compounds the effectiveness of these solvents for the extraction of phenolic compounds was significantly better than of the pure organic solvents (methanol and ethanol) for all sample materials. Obviously, the selectivity of mixtures between water and organic solvents showed a higher selectivity for the extraction of phenolic compounds than water or organic solvents alone. This was similar to the results reported by Siddhuraju and Becker (2003). Other 

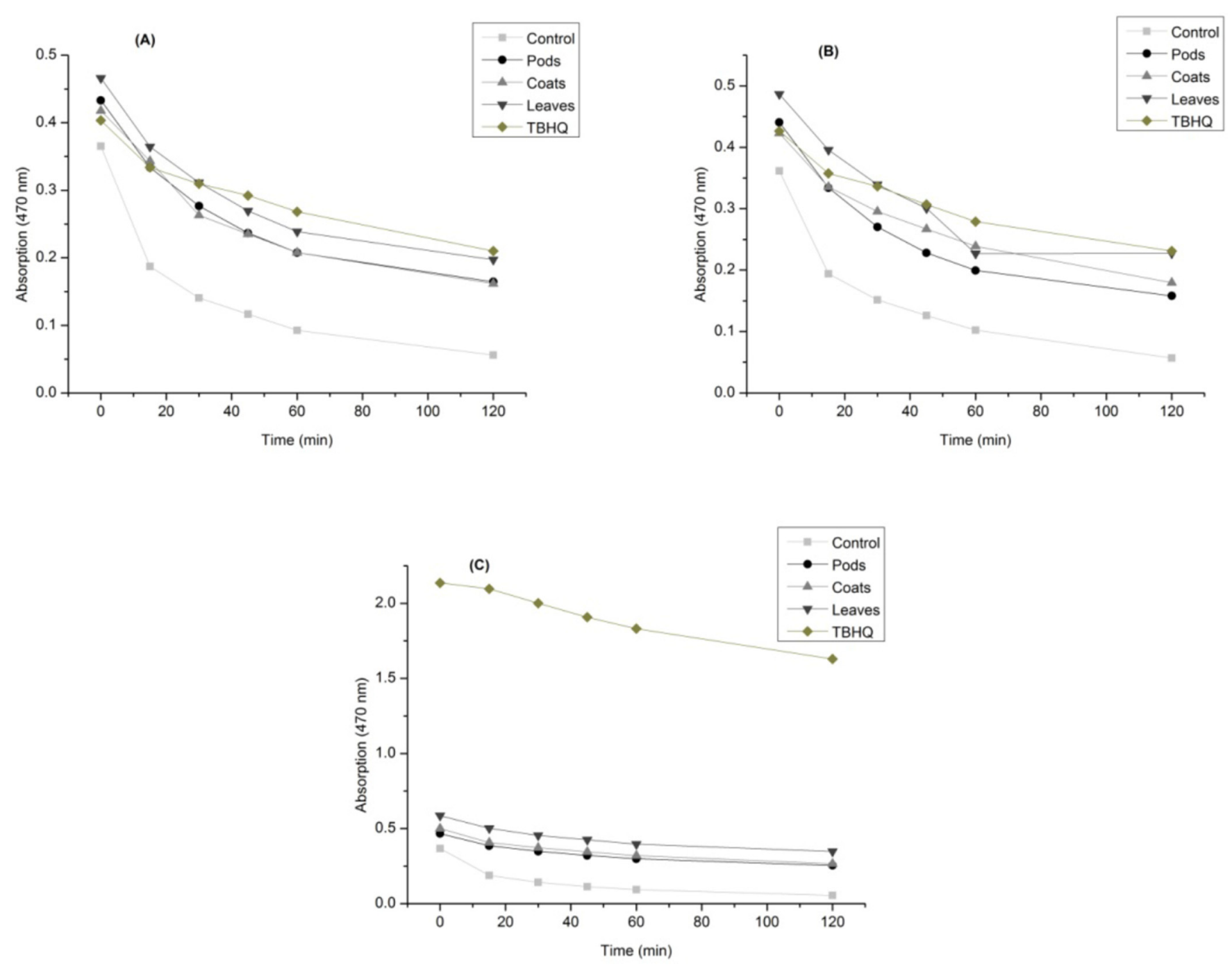

Fig. 4. Antioxidant activity of Moringa oleifera (leaves, pods and coats extracts) by using B-Carotene/linoleic acid bleaching method. (A) $5 \mathrm{mg} / \mathrm{mL}$. (B) $10 \mathrm{mg} / \mathrm{mL}$. (C) $30 \mathrm{mg} / \mathrm{mL}$.

papers also showed that phenolic compounds are better soluble in polar compounds due to their polar moiety (Barchan et al., 2014; Haminiuk et al., 2014). Leaves had the highest amount of TPC in comparison to the other materials and reached 11.8, 11.3 and $8.9 \mathrm{mg} \mathrm{GAE} / \mathrm{g}$ by using $70 \%$ ethanol, $80 \%$ methanol and water, respectively. El Sohaimy et al. (2015) showed that methanol extract from MO leaves had the highest amount of TPC (48.4 mg GAE/g). The current results revealed also low amount of TPC by using ethanol (5.6 $\mathrm{mg} \mathrm{GAE} / \mathrm{g}$ ) compared to methanol extract $(7.1 \mathrm{mg} \mathrm{GAE} / \mathrm{g})$ in leaves.

This is in agreement with Gull et al. (2016) and Urías-Orona et al. (2017) who recorded that methanol moringa leaf extracts contained more TPC than ethanol extract. Using water as extraction solvent resulted in the highest values of TPC for coats $(1.2 \mathrm{mg} \mathrm{GAE} / \mathrm{g})$, pods $(1.7 \mathrm{mg} \mathrm{GAE} / \mathrm{g})$, whole seeds $(1.6 \mathrm{mg} \mathrm{GAE} / \mathrm{g})$ and kernels $(1.3 \mathrm{mg} \mathrm{GAE} / \mathrm{g})$, respectively. While using $70 \%$ ethanol recorded the highest value in leaves (11.8 $\mathrm{mg} \mathrm{GAE} / \mathrm{g})$.

Using acetone resulted in the lowest yield of total extractable compounds and total phenolic contents. It was
4.6, 5.1, 1.4, 4.8 and $7.9 \%$ as total extractable compounds and

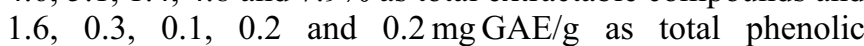
compounds, respectively, in leaves, coats, pods, whole seeds and kernels. This is comparable to Proestos and Komaitis (2006) who reported that using solvents low in polarity resulted in a decrease of the amount of phenolic compounds.

The results reveal that only leaves contain considerable amounts of phenolic compounds with highest yields for extraction with $70 \%$ ethanol and $80 \%$ methanol, respectively. For the other materials, TPC was below 2 which makes a use of these materials for the provision of phenolic compounds uninteresting if the antioxidant activity of the extracts is not unusually high. It also becomes clear that no correlation between the amount of extractable compounds and TPC was found.

It must be taken into consideration that the Folin-Ciocalteau reagent is not specific only for phenolic compounds but also for other reducing compounds such as sugars, ascorbic acid, amino acids, peptides, etc (Singleton and Rossi, 1965; Everette et al., 2010; Sánchez-Rangel et al., 2013). From this, it can be 
assumed that the extraction with more polar solvents results in higher extraction rates for soluble solids but not necessarily to the extraction of higher levels of phenolic compounds. This explains why no correlation between total extractable and total phenolic compounds was found.

Water was found as the best solvent for the extraction rate but with low content of phenolic compounds. It can be assumed that by water mainly water soluble compounds such as sugars or organic acids were extracted (Miller et al., 1995).

\subsection{Antioxidant activity by DPPH assay and B- carotene bleaching method}

For the assessment of the quality of an extract from plants not only the total amount of phenolic compounds is decisive but more important is the antioxidant activity of the extract. This information gives some indication on the effectiveness of the extract to limit oxidative reactions.

In the present work, the antioxidant activity was measured by the DPPH assay (Fig. 3C) and by the B-carotene bleaching method (Figs. 4A-4C) measuring the degradation of $\beta$-carotene resulting from the oxidation of linoleic acid. In the first case, the extract provides the hydrogen atom to the free radical and in the second case linoleic acid is stabilized by the extract.

In general, the structure of the phenolic compounds, and here especially the number and position of the hydroxyl groups and the type of other substitutions of the aromatic ring determine the antioxidant activity (Balasundram et al., 2006).

\subsubsection{DPPH assay}

DPPH free radical protocol was used to measure the ability of the extracts obtained from the different parts of MO to stabilize free radicals by forming stable diamagnetic molecules (Singh et al., 2009). The result is given as amount of sample necessary to decrease the initial DPPH concentration by $50 \%$. The lower the amount of extract necessary to reduce the amount of DPPH by $50 \%$, the higher is the antioxidant activity of the extract.

The different extracts of MO were able to reduce the stable radical DPPH to the yellow colored diphenyl picryl hydrazine. For all solvents, leaves of MO showed the highest antioxidant activity in comparison to the other plant materials indicated by the lowest ED50 values (Fig. 3C). Extracts from leaves obtained by $70 \%$ ethanol and $80 \%$ methanol showed the highest antioxidant activities $(0.51$ and $0.54 \mathrm{mg})$ followed by methanol $(0.83 \mathrm{mg})$, ethanol $(0.98 \mathrm{mg})$, water $(1.09 \mathrm{mg})$ and acetone $(1.62 \mathrm{mg})$. These results were in a harmony with Urías-Orona et al. (2017) who mentioned that $100 \%$ methanol was better than $100 \%$ ethanol in DPPH assay, while $80 \%$ ethanol showed better results in DPPH assay than $80 \%$ methanol.

Of the other materials, only extracts from coats obtained by $80 \%$ methanol and water showed antioxidant activity comparable to extracts from leaves. The results also revealed that samples with higher content of TPC resulted in a better antioxidant activity.

\subsubsection{B-carotene-linoleic acid assay}

In this method, a model system made of $\beta$-carotene and linoleic acid undergoes a discoloration in the disappearance of an antioxidant. The free linoleic acid radical formed upon the abstraction of a hydrogen atom from a methylene group attacks the $\beta$-carotene molecules, which losses double bonds and, therefore, its special orange color.

Antioxidants can prevent the range of $\beta$-carotene-bleaching by neutralizing the linoleate-free radical and other free radicals in the system (Jayaprakasha et al., 2001). Figures 4A-4C showed the absorbance of $\beta$-carotene in the existence of $70 \%$ ethanol extracts from leaves and pods and $80 \%$ methanol extract from coats (the highest results in DPPH assay) in comparison to the control without antioxidant and TBHQ as a standard antioxidant.

Since extracts from seeds and kernels only show a low antioxidant activity in the DPPH assay, they were not further investigated. The results showed that antioxidant activity measured by the $\beta$-carotene-linoleic acid model system, was in harmony with the DPPH data. Leaves extract showed the greatest delaying for the oxidation in all concentration followed by the extract from coats and pods.

Natural extract at 5 and $10 \mathrm{mg} / \mathrm{mL}$ from leaves had antioxidant activities more than TBHQ till $30 \mathrm{~min}$, then TBHQ was more activity till $120 \mathrm{~min}$, while extracts from coats and pods recorded antioxidant activities more than TBHQ till $15 \mathrm{~min}$ at $5 \mathrm{mg} / \mathrm{mL}$ only (Figs. $4 \mathrm{~A}$ and $4 \mathrm{~B}$ ). Generally, phenolic compounds extract from leaves had more activity than the others.

TBHQ showed the high effective action for delaying the oxidation at $30 \mathrm{mg} / \mathrm{mL}$ (Fig. $4 \mathrm{C}$ ). In the $\beta$-carotene-linoleic acid model system, it could be observed that results were in a harmony with the data recorded for DPPH test. The leaves extract had the highest delaying for the oxidation at all used concentrations followed by coats and pods extracts.

\section{Conclusion}

The results of this study have shown that MO seeds are a good source for high amounts of oleic acid. Unusual for common used edible oils is the high amount of behenic acid and vaccenic acid. In addition, the seeds are not only a good source for oil but also for protein and fibre that are enriched in the residue by oil extraction. Different parts of MO are also suitable to overcome a shortage of protein in animal and human nutrition. The residue of the oil extraction also contains high amounts of minerals with $\mathrm{Mg}$ and $\mathrm{K}$ as most important compounds making the residue to an interesting source for these compounds. The other parts of the plant such as pods, leaves or the coats from the seeds are also interesting sources for valuable compounds usable in nutrition. Especially, the leaves are high in minerals and antioxidant phenolic compounds, but they also contain higher amounts of protein $(22 \%)$ and carbohydrates $(38.1 \%)$. From this, the use of leaves from MO seems to be a recommendable addition to human nutrition. It is interesting that the content and the antioxidant activity of extracts from different parts of the plant with respect to a sustainable use of resources. 


\section{Conflict of interest}

The authors declare that they have no conflict of interest.

Acknowledgement. The authors are most grateful for the financial support provided by the Ministry of Higher Education and Scientific Research, Egypt, and the technical support provided by the members of the Working Group of Lipid Research at the Department for Safety and Quality for Cereals in Detmold, Germany of the Max-Rubner-Institut.

\section{References}

Abdulkarim S, Long K, Lai O, Muhammad S, Ghazali H. 2005. Some physico-chemical properties of Moringa oleifera seed oil extracted using solvent and aqueous enzymatic methods. Food Chem 93: 253-263. https://doi.org/10.1016/j.food chem.2004.09.023.

Abdulkarim S, Long K, Lai OM, Muhammad S, Ghazali H. 2007. Frying quality and stability of high-oleic Moringa oleifera seed oil in comparison with other vegetable oils. Food Chem 105: 1382-1389. https://doi.org/10.1016/j.food chem.2007.05.013.

Abiodun O, Adegbite J, Omolola A. 2012. Chemical and physicochemical properties of moringa flours and oil. Glob J Sci Front Res Biol Sci 12: 1-7.

Al Juhaimi F, Ghafoor K, Babiker EE, Matthäus B, Özcan MM. 2017. The biochemical composition of the leaves and seeds meals of moringa species as non-conventional sources of nutrients. J Food Biochem 41: e12322. https://doi.org/10.1111/jfbc.12322.

Alsmeyer RH, Cunningham AE, Happich ML. 1974. Equation to predict protein efficiency ratio (PER) from amino acid analysis. Food Technol 28: 34-38.

Amaechi NC, Njoku B, Adiele AM. 2015. Evaluation of the amino acid profile of Cnidoscolus acontifolius and Ceiba pentandra leaves grown in southeast Nigeria. Int J Pure Appl Res Eng Technol 4: 88-95.

Amagloh FK, Benang A. 2009. Effectiveness of Moringa oleifera seed as coagulant for water purification. Afr J Agric Res 4: 119-123.

Anwar F, Bhanger M. 2003. Analytical characterization of Moringa oleifera seed oil grown in temperate regions of Pakistan. J Agric Food Chem 51: 6558-6563. https://doi.org/10.1021/ jf0209894.

Anwar F, AshrafM, Bhanger MI. 2005. Interprovenance variation in the composition of Moringa oleifera oilseeds from Pakistan. J Am Oil Chem Soc 82: 45-51. https://doi.org/10.1007/s11746-005-1041-1.

Anwar F, Latif S, Ashraf M, Gilani AH. 2007. Moringa oleifera: A food plant with multiple medicinal uses. Phytother Res 21: 17-25. https://doi.org/10.1002/ptr.2023.

AOAC (Association of Official Analytical Chemists). 2010. Official method of analysis (20th ed.). Washington, DC: Association of Official Analytical Chemist.

Balasundram N, Sundram K, Samman S. 2006. Phenolic compounds in plants and agri-industrial by-products: Antioxidant activity, occurrence, and potential uses. Food Chem 99: 191-203. https:// doi.org/10.1016/j.foodchem.2005.07.042.

Banov D, Banov F, Bassani AS. 2014. Case series: The effectiveness of fatty acids from pracaxi oil in a topical silicone base for scar and wound therapy. Dermatol Ther 4: 259-269. https://doi.org/ 10.1007/s13555-014-0065-y.

Barchan A, Bakkali M, Arakrak A, Pagán R, Laglaoui A. 2014. The effects of solvents polarity on the phenolic contents and antioxidant activity of three Mentha species extracts. Int J Curr Microbiol App Sci 3(11): 399-412.

Brilhante RS, Sales JA, Pereira VS, et al. 2017. Research advances on the multiple uses of Moringa oleifera: A sustainable alternative for socially neglected population. Asian Pac J Trop Med 10(7): 621-630. https://doi.org/10.1016/j.apjtm.2017.07.002.

Carré P, Citeau M, Robin G, Estorges M. 2016. Hull content and chemical composition of whole seeds, hulls and germs in cultivars of rapeseed (Brassica napus). OCL 23(3): A302. https://doi.org/ 10.1051/ocl/2016013.

Codex Alimentarius Commission. 2019. Codex Alimentarius Commission and Report of the 30th Session of the Codex Committee on Nutrition and Foods for Special Dietary Uses.

Compaoré W, Nikièma $\mathrm{P}$, Bassolé $\mathrm{H}$, Savadogo $\mathrm{A}$, Mouecoucou J. 2011. Chemical composition and antioxidative properties of seeds of Moringa oleifera and pulps of Parkia biglobosa and Adansonia digitata commonly used in food fortification in Burkina Faso. Curr Res J Biol Sci 3: 64-72.

Deutsche Gesellschaft für Fettwissenschaften (DGF). 2013. German methods for the analysis of fats and other lipids, C-VI 10 (13), C-VI 11d (98). Stuttgart: Wissenschaftliche VerlagsgesellschaftmbH.

Duranti M, Cerletti P. 1979. Amino acid composition of seed proteins of Lupinus albus. J Agric Food Chem 27: 977-978. https://doi. org/10.1021/jf60225a038.

El Sohaimy SA, Hamad GM, Mohamed SE, Amar MH, Al-Hindi RR. 2015. Biochemical and functional properties of Moringa oleifera leaves and their potential as a functional food. Glob Adv Res $J$ Agric Sci 4: 188-199.

El-Massry FH, Mossa M, Youssef S. 2013. Moringa oleifera plant "Value and utilization in food processing". Egypt J Agric Res 91: 1597-1609.

Everette JD, Bryant QM, Green AM, Abbey YA, Wangila GW, Walker RB. 2010. Thorough study of reactivity of various compound classes toward the Folin-Ciocalteu reagent. J Agric Food Chem 58(14): 8139-44.

FAO/UN/WHO, Food and Agricultural Organization of the United Nations World Health Organization. 1991. Protein Quality Evaluation: Report of Joint FAO/WHO Expert Consultation. FAO Food and Nutrition Paper 51. Rome: FAO, 19:21:180.

FDA. 2001. Agency Response Letter. GRAS Notice No. 000069. Washington DC.

Fernandes DM, Sousa RM, de Oliveira A, Morais SA, Richter EM, Muñoz RA. 2015. Moringa oleifera: A potential source for production of biodiesel and antioxidant additives. Fuel 146: 75-80. https://doi.org/10.1016/j.fuel.2014.12.081.

Friedman M. 1996. Nutritional value of proteins from different food sources. A review. J Agric Food Chem 44: 6-29. https://doi.org/ 10.1021/jf9400167.

Gharby S, Harhar H, Farssi M, Taleb AA, Guillaume D, Laknifli A. 2018. Influence of roasting olive fruit on the chemical composition and polycyclic aromatic hydrocarbon content of olive oil. OCL 25(3): A303. https://doi.org/10.1051/ocl/2018013.

Gharby S, Hajib A, Ibourki M, et al. 2021. Induced changes in olive oil subjected to various chemical refining steps: A comparative study of quality indices, fatty acids, bioactive minor components, and oxidation stability kinetic parameters. Chem Data Collect 33: 100702. https://doi.org/10.1016/j.cdc.2021.100702.

Gopalakrishnan L, Doriya K, Kumar DS. 2016. Moringa oleifera: A review on nutritive importance and its medicinal application. Food Sci Human Wellness 5: 49-56. https://doi.org/10.1016/j. fshw.2016.04.001.

Gowrishankar R, Kumar M, Menon V, et al. 2010. Trace element studies on Tinospora cordifolia (Menispermaceae), 
Ocimum sanctum (Lamiaceae), Moringa oleifera (Moringaceae), and Phyllanthus niruri (Euphorbiaceae) using PIXE. Biol Trace Elem Res 133: 357-363. https://doi.org/10.1007/s12011-0098439-1.

Grigonis D, Venskutonis PR, Sivik B, Sandahl M, Eskilsson CS. 2005. Comparison of different extraction techniques for isolation of antioxidants from sweet grass (Hierochloë odorata). $J$ Supercrit Fluids 33(3): 223-33. https://doi.org/10.1016/j. supflu.2004.08.006.

Gull I, Javed A, Aslam MS, Mushtaq R, Athar MA. 2016. Use of Moringa oleifera flower pod extract as natural preservative and development of SCAR marker for its DNA based identification. BioMed Res Int ID 7584318. https://doi.org/101155/2016/ 7584318.

Guo S, Ge Y, Jom KN. 2017. A review of phytochemistry, metabolite changes, and medicinal uses of the common sunflower seed and sprouts (Helianthus annuus L.). Chem Cent J 11: 95. https://doi. org/10.1186/s13065-017-0328-7.

Haminiuk CW, Plata-Oviedo MS, de Mattos G, Carpes ST, Branco IG. 2014. Extraction and quantification of phenolic acids and flavonols from Eugenia pyriformis using different solvents. J Food Sci Technol 51(10): 2862-6. https://doi.org/10.1007/ s13197-012-0759-z.

Hatano T, Kagawa H, Yasuara T, Okuda T. 1988. Two new flavonoids and other constituents in licorice root: Their relative astringency and radical scavenging effects. Chem Pharm Bull 36: 2090-2097. https://doi.org/10.1248/cpb.36.2090.

ISO 659. 2009. Oilseeds - Determination of oil content (Reference method). EN ISO 659.

Jahn SAA. 1988. Using moringa seeds as coagulants in developing countries. J Am Water Works Assoc 80: 43-50. https://doi.org/ 10.1002/j.1551-8833.1988.tb03052.x.

Jara-Palacios M, Hernanz D, Cifuentes-Gómez T, Escudero-Gilete M, Heredia JH, Spencer JPE. 2015. Assessment of white grape pomace form winemaking as source of bioactive compounds, and its antiproliferative activity. Food Chem 183: 78-82.

Jayaprakasha G, Singh R, Sakariah K. 2001. Antioxidant activity of grape seed (Vitis vinifera) extracts on peroxidation models in vitro. Food Chem 73: 285-290. https://doi.org/10.1016/ S0308-8146(00)00298-3.

Kalo P, Kemppinem A. 2003. Triglycerides/structures and properties. Encycl Food Sci Nutr 5857-5868.

Kasolo JN, Bimenya GS, Ojok L, Ochieng J, Ogwal-Okeng JW. 2010. Phytochemicals and uses of Moringa oleifera leaves in Ugandan rural communities. J Med Plants Res 4(9): 753-757. https://doi. org/10.5897/JMPR10.492.

Kleiman R, Ashley DA, Brown JH. 2008. Comparison of two seed oils used in cosmetics, moringa and marula. Ind Crops Prod 28: 361-364. https://doi.org/10.1016/j.indcrop.2008.04.003.

Konuskan DB, Arslan M, Oksuz A. 2019. Physicochemical properties of cold pressed sunflower, peanut, rapeseed, mustard and olive oils grown in the Eastern Mediterranean region. Saudi J Biol Sci 26(2): 340-344. https://doi.org/10.1016/j.sjbs.2018.04.005.

Kuku-Shittu O, Onabanjo O, Fadare O, Oyeyemi M. 2016. Child malnutrition in Nigeria: Evidence from Kwara State. Intl Food Policy Res Inst.

Lalas S, Tsaknis J. 2002. Characterization of Moringa oleifera seed oil variety "Periyakulam 1". J Food Compos Anal 15: 65-77. https://doi.org/10.1006/jfca.2001.1042.

Layman DK, Walker DA. 2006. Potential importance of leucine in treatment of obesity and the metabolic syndrome. J Nutr 136: 319S-323S. https://doi.org/10.1093/jn/136.1.319S.

Ma ZF, Ahmad J, Zhang H, Khan I, Muhammad S. 2020. Evaluation of phytochemical and medicinal properties of Moringa
(Moringa oleifera) as a potential functional food. Saudi J Biol Sci 129: 40-6. https://doi.org/10.1016/j.sajb.2018.12.002.

Marrufo T, Nazzaro F, Mancini E, et al. 2013. Chemical composition and biological activity of the essential oil from leaves of Moringa oleifera Lam. cultivated in Mozambique. Molecules 18: 10989-11000. https://doi.org/10.3390/molecules180910989.

Martinez-Correa HA, Magalhães PM, Queiroga CL, Peixoto CA, Oliveira AL, Cabral FA. 2011. Extracts from pitanga (Eugenia uniflora L.) leaves: Influence of extraction process on antioxidant properties and yield of phenolic compounds. J Supercrit Fluids 55(3): 998-1006. https://doi.org/10.1016/j.supflu.2010.09.001.

Melesse A. 2011. Comparative assessment on chemical compositions and feeding values of leaves of Moringa stenopetala and Moringa oleifera using in vitro gas production method. Ethiop J Sci Technol 2: 31-41.

Miller NJ, Diplock AT, Riceevans CA. 1995. Evaluation of the total antioxidant activity as a marker of the deterioration of apple juice oil storage. J Agric Food Chem 43: 1794-1801. https://doi.org/ 10.1021/jf00055a009.

Morton JF. 1991. The horseradish tree, Moringa pterygosperma (Moringaceae) a boon to arid lands? Econ Bot 45: 318-333. https://doi.org/10.2307/4255362.

Moyo B, Masika PJ, Hugo A, Muchenje V. 2011. Nutritional characterization of Moringa (Moringa oleifera Lam.) leaves. Afr J Biotechnol 10: 12925-12933. https://doi.org/10.5897/ AJB10.1599.

Mukunzi D, Nsor-Atindana J, Xiaoming Z, Gahungu A, Karangwa E, Mukamurezi G. 2011. Comparison of volatile profile of Moringa oleifera leaves from Rwanda and China using HS-SPME. Pak J Nutr 10: 602-608. https://doi.org/10.3923/ pjn.2011.602.608.

Nadeem M, Imran M. 2016. Promising features of Moringa oleifera oil: Recent updates and perspectives. Lipids Health Dis 15(1): 1-8. https://doi.org/10.1186/s12944-016-0379-0.

Nguyen HN, Pag-asa DG, Maridable JB, et al. 2011. Extraction of oil from Moringa oleifera kernels using supercritical carbon dioxide with ethanol for pretreatment: Optimization of the extraction process. Chem Eng Process: Process Intensif 50: 1207-1213. https://doi.org/10.1016/j.cep.2011.08.006.

Nzikou J, Matos L, Moussounga J, et al. 2009. Characterization of Moringa oleifera seed oil variety Congo-Brazzaville. J Food Technol 7: 59-65. https://doi.org/10.3989/gya.1999.v50.i1.634.

Okereke CJ, Akaninwor JO. 2013. The protein quality of raw leaf, seed and root of Moringa oleifera grown in Rivers State, Nigeria. Ann Biol Res 4: 34-38.

Pandey KB, Rizvi SI. 2009. Plant polyphenols as dietary antioxidants in human health and disease. Oxid Med Cell Longev 2: 270-278. https://doi.org/10.4161/oxim.2.5.9498.

Proestos C, Komaitis M. 2006. Ultrasonically assisted extraction of phenolic compounds from aromatic plants: Comparison with conventional extraction technics. J Food Qual 29: 567-582. https://doi.org/10.1111/j.1745-4557.2006.00096.x.

Rahman IM, Barua S, Nazimuddin M, Begum ZA, Rahman MA, Hasegawa H. 2009. Physicochemical properties of Moringa oleifera Lam. seed oil of the indigenous-cultivar of bangladesh. JFood Lipids 16: 540-553. https://doi.org/10.1111/j.1745-4522.2009.01165.x.

Rahman MM, Rahman MM, Akhter S, et al. 2010. Control of coliform bacteria detected from diarrhea associated patients by extracts of Moringa oleifera. Nepal Med Coll J 12(1): 12-9.

Rashid U, Anwar F, Moser BR, Knothe G. 2008. Moringa oleifera oil: A possible source of biodiesel. Bioresour Technol 99: 8175-8179. https://doi.org/10.1016/j.biortech.2008.03.066.

$\mathrm{Raß}$ M, Schein C, Matthäus B. 2008. Virgin sunflower oil. Eur J Lipid Sci Technol 110(7): 618-24. https://doi.org/10.1002/ejlt.200800049. 
Salama MA, Owon MA, Osman MF, Ibrahim A, Matthäus B. 2020. Effect of germination and roasting on oil profile of Moringa oleifera and Moringa peregrina seeds. Food Meas 14: 2220-2229. https://doi.org/10.1007/s11694-020-00469-2.

Sánchez-Rangel JC, Benavides J, Heredia JB, Cisneros-Zevallos L, Jacobo-Velázquez DA. 2013. The Folin-Ciocalteu assay revisited: Improvement of its specificity for total phenolic content determination. Anal Method 5(21): 5990-5999. https:// doi.org/10.1039/c3ay41125g.

Seo JS, Sohn HB, Noh K, et al. 2012. Expression of the Arabidopsis AtMYB44 gene confers drought/salt-stress tolerance in transgenic soybean. Mol Breed 29(3): 601-8. https://doi.org/ 10.1007/s11032-011-9576-8.

Siddhuraju P, Becker K. 2003. Antioxidant properties of various solvent extracts of total phenolic constituents from three different agro climatic origins of drumstick tree (Moringa oleifera Lam.) leaves. J Agric Food Chem 51: 2144-2155. https://doi.org/ 10.1021/jf020444+.

Singh BN, Singh B, Singh R, et al. 2009. Oxidative DNA damage protective activity, antioxidant and anti-quorum sensing potentials of Moringa oleifera. Food Chem Toxicol 47: 1109-1116. https://doi.org/10.1016/j.fct.2009.01.034.

Singleton VL, Rossi JA. 1965. Colorimetry of total phenolics with phosphomolybdic-phosphotungstic acid reagents. Am J Enol Vitic 16(3): 144-158.
Sultan SM, Dikshit N, Vaidya UJ. 2015. Oil content and fatty acid composition of soybean (Glysine max L.) genotypes evaluated under rainfed conditions of Kashmir Himalayas in India. J Appl Nat Sci 7(2): 910-915. https://doi.org/10.31018/jans. v7i2.706.

Taga MS, Miller E, Pratt D. 1984. Chia seeds as a source of natural lipid antioxidants. J Am Oil Chem Soc 61: 928-931. https://doi. org/10.1007/bf02542169.

Tsaknis J, Lalas S, Gergis V, Dourtoglou V, Spiliotis V. 1999. Characterization of Moringa oleifera variety Mbololo seed oil of Kenya. J Agric Food Chem 47: 4495-4499. https://doi.org/ $10.1021 /$ jf9904214.

Urías-Orona V, Gutiérrez-Soto G, Ruiz-Bautista J, et al. 2017. Influence of extraction solvent on phenolic content and antioxidant capacity level of a commercial food supplement from Moringa oleifera leaves. Arch Latinoam Nutr 67(3): 211-217.

Verma AR, Vijayakumar M, Mathela CS, Rao CV. 2009. In vitro and in vivo antioxidant properties of different fractions of Moringa oleifera leaves. Food Chem Toxicol 47: 2196-2201. https://doi.org/10.1016/j.fct.2009.06.005.

Xie Y, Wei F, Xu S, et al. 2019. Profiling and quantification of lipids in cold-pressed rapeseed oils based on direct infusion electrospray ionization tandem mass spectrometry. Food Chem 285: 194-203.

Cite this article as: Owon M, Osman M, Ibrahim A, Salama MA, Matthäus B. 2021. Characterisation of different parts from Moringa oleifera regarding protein, lipid composition and extractable phenolic compounds. OCL 28: 45. 